\title{
Effects of Crystallization on the Corrosion and Passivity of Amorphous Pd-Fe-Co-Si-B Alloys
}

\author{
HeeJin Jang, ${ }^{1}$ Han-Ok Lee, ${ }^{1}$ and Hyun-Goo Kim ${ }^{2}$ \\ ${ }^{1}$ Department of Materials Science and Engineering, Chosun University, 309 Pilmundaero, Dong-gu, Gwangju 61452, Republic of Korea \\ ${ }^{2}$ Department of Physics Education, Chosun University, 309 Pilmundaero, Dong-gu, Gwangju 61452, Republic of Korea \\ Correspondence should be addressed to HeeJin Jang; heejin@chosun.ac.kr
}

Received 9 January 2017; Revised 3 April 2017; Accepted 8 May 2017; Published 28 May 2017

Academic Editor: Yuliya Demidova

Copyright (c) 2017 HeeJin Jang et al. This is an open access article distributed under the Creative Commons Attribution License, which permits unrestricted use, distribution, and reproduction in any medium, provided the original work is properly cited.

Corrosion behavior of $\mathrm{Pd}_{48.2} \mathrm{Fe}_{17} \mathrm{Co}_{16.7} \mathrm{Si}_{13.4} \mathrm{~B}_{4.7}$ and $\mathrm{Pd}_{51.4} \mathrm{Fe}_{18} \mathrm{Co}_{18} \mathrm{Si}_{11.1} \mathrm{~B}_{1.5}$ alloys was examined by potentiodynamic polarization tests in $\mathrm{pH} 8.5$ buffer solution. The amorphous alloy ribbons showed passivity with the passive current densities of $2 \times 10^{-6} \mathrm{~A} / \mathrm{cm}^{2} \sim 4$ $\times 10^{-6} \mathrm{~A} / \mathrm{cm}^{2}$. The crystalline alloys showed a higher corrosion rate in $\mathrm{pH} 8.5$ buffer solution with the degree of variation depending on the alloy composition. It is suggested from the Mott-Schottky analysis that the donor density was lower for the amorphous alloy than the crystalline alloy.

\section{Introduction}

Amorphous alloys have excellent strength and elasticity and easily formed into desired shape [1] due to their peculiar microstructure. By using amorphous alloys, it is possible to produce mechanical parts that have lifetimes hundred times longer than conventional steels [2]. Superior mechanical properties and durability are ideal for high strength and lightweight applications, including for high quality sports goods and portable devices. Co- and Fe-based amorphous alloys are under interest because they exhibit soft magnetism and low magnetostriction and hence are suitable in electronic devices such as GMI biosensors [3-5]. Pd-B amorphous alloys have been proposed as promising materials for catalysts in drug manufacturing processes due to their high activity, selectivity, and stability [6]. It is also reported that amorphous $\mathrm{Pd}_{33} \mathrm{Ni}_{60} \mathrm{P}_{7}$ alloy shows higher activity than crystalline $\mathrm{Pd}, \mathrm{Ni}$, and $\mathrm{Pd}-\mathrm{Ni}$ for the electrocatalytic reduction of $\mathrm{NO}_{3}{ }^{-}$due to its amorphous structure [7]. As mentioned above, amorphous alloys will be innovative materials that play an important role in future industries like lightweight products, environmental management, biotechnology, health care, and so on.

Corrosion resistance is one of the most important factors determining the durability of industrial products. The corrosion or electrochemical properties of Pd-based alloys are particularly important because they are mainly supposed to be used as catalysts or in biomedical field. Amorphous alloys are generally known to be more resistant to corrosion than crystalline materials $[2,3,8]$. However, some studies on amorphous $\mathrm{Fe}_{73.5} \mathrm{Si}_{13.5} \mathrm{~B}_{9} \mathrm{Cu}_{1} \mathrm{Nb}_{3}$ [9], $\mathrm{Cu}_{43} \mathrm{Zr}_{43} \mathrm{Al}_{7} \mathrm{Be}_{7}$ [10], and $\mathrm{Pd}_{40} \mathrm{Ni}_{40} \mathrm{P}_{20}$ alloys [11] show improved corrosion resistance after heat treatment. The reason that makes the alloys more resistant to corrosion is proposed as structural relaxation and nanocrystallization [9], reduced internal energy associated with the annihilation of excess free volume [10], or noble phases evolved by crystallization [11].

Despite the high interest in amorphous alloys, the corrosion properties of amorphous alloys have rarely been studied in depth. The research reports on the corrosion of amorphous alloys are confined to a few alloy systems and they have provided basic information on the corrosion rate at some specific environments, while corrosion behaviors of crystalline materials have been studied extensively and intensively for lots of metals and alloys. In addition, the corrosion and passivity of amorphous alloys are also considered to provide insight into corrosion mechanisms. This is because amorphous metals and alloys do not have inhomogeneity due to grain boundaries, which are indispensable for polycrystalline materials and which promote corrosion. A comparative study of the properties of passive films formed on amorphous and 


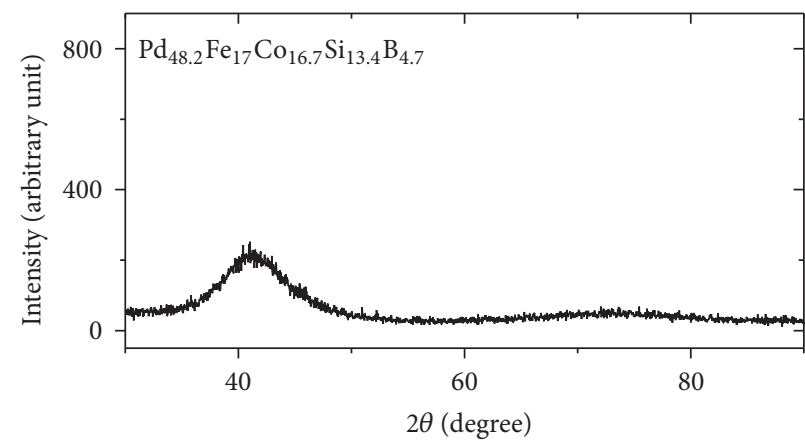

(a) As-cast

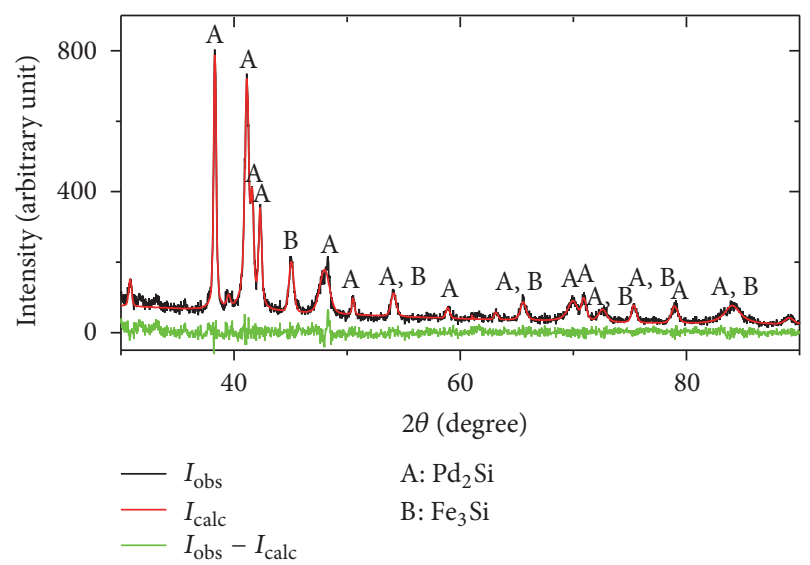

(b) Annealed

FIGURE 1: XRD patterns for (a) amorphous and (b) crystallized $\mathrm{Pd}_{48.2} \mathrm{Fe}_{17} \mathrm{Co}_{16.7} \mathrm{Si}_{13.4} \mathrm{~B}_{4.7}$ alloys.

crystalline alloys is expected to provide some intimation of the effect of microstructure on corrosion resistance.

The corrosion resistance of passive alloys is determined by the passive film essentially. The protectiveness of the passive film is anticipated to be highly related to the type and concentration of the point defects such as oxygen vacancy or metal vacancy, because oxidation or dissolution of metal occurs by transport of ions through the passive film. However the mechanism by which the defect properties of passive film affect the corrosion resistance is still not so clearly defined, and more experimental evidence is needed [12].

In this study, we aimed to investigate the electrochemical properties of amorphous $\mathrm{Pd}-\mathrm{Fe}-\mathrm{Co}-\mathrm{Si}-\mathrm{B}$ alloys in comparison with the crystalline alloys with the same compositions, focusing on the defect properties of the passive film. The corrosion behavior of amorphous and crystallized $\mathrm{Pd}_{48.2} \mathrm{Fe}_{17} \mathrm{Co}_{16.7} \mathrm{Si}_{13.4} \mathrm{~B}_{4.7}$ and $\mathrm{Pd}_{48.2} \mathrm{Fe}_{17} \mathrm{Co}_{16.7} \mathrm{Si}_{13.4} \mathrm{~B}_{4.7}$ alloy in $\mathrm{pH} 8.5$ buffer solution was examined by potentiodynamic polarization tests. The conduction type and the densities of point defect in the passive films were determined by MottSchottky analysis.

\section{Experimental Procedures}

Alloy ingots were prepared by arc-melting a mixture of pure $\mathrm{Pd}, \mathrm{Fe}, \mathrm{Co}, \mathrm{Si}$, and $\mathrm{B}$ metals in a purified argon atmosphere to give compositions of $\mathrm{Pd}_{48.2} \mathrm{Fe}_{17} \mathrm{Co}_{16.7} \mathrm{Si}_{13.4} \mathrm{~B}_{4.7}$ and $\mathrm{Pd}_{51.4} \mathrm{Fe}_{18} \mathrm{Co}_{18} \mathrm{Si}_{11.1} \mathrm{~B}_{1.5}$ with the nominal composition being expressed in atomic percent. The amorphous alloy ribbon was prepared using a single-roller melt-spinning technique in an argon atmosphere. Crystalline alloy was obtained by heating an amorphous alloy ribbon at $550^{\circ} \mathrm{C}$ for $5 \mathrm{~min}$.

The structure of the samples was confirmed by X-ray diffractometry. A $\mathrm{Cu} \mathrm{K} \alpha$ radiation, $\mathrm{Ni}$-filtered, at a voltage of $40 \mathrm{kV}$ and a current of $30 \mathrm{~mA}$ was used. The pattern was measured over a $2 \theta$ range of $10 \sim 100^{\circ}$ at a scan rate of $8^{\circ} / \mathrm{min}$.

Corrosion properties of the amorphous and crystalline alloys were examined in deaerated buffer solutions at $\mathrm{pH}$ of 8.5 at an ambient temperature, using a traditional 3-electrode electrochemical cell. The sample with exposed area of about $0.3 \mathrm{~cm}^{2}$ was used as working electrode. A saturated calomel electrode (SCE) and a Pt wire were used as reference and counter electrodes, respectively.

Mott-Schottky analysis was performed to compare the density of point defects in the passive films of the amorphous and the crystalline alloys. Passive films were formed at $0.5 \mathrm{~V}_{\mathrm{SCE}}$ for 2 or $24 \mathrm{~h}$ before measurement. And then capacitance was measured at $1000 \mathrm{~Hz}$ with the amplitude of $10 \mathrm{mV}$, scanning the potential from the film formation potential to $-1 \mathrm{~V}_{\mathrm{SCE}}$.

The electrochemical tests were performed two or three times to ensure reproducibility and the average values of corrosion potential, corrosion rate, and defect density are presented in the following section.

\section{Results and Discussion}

Figures 1 and 2 are the $\mathrm{XRD}$ patterns for $\mathrm{Pd}_{48.2} \mathrm{Fe}_{17} \mathrm{Co}_{16.7} \mathrm{Si}_{13.4} \mathrm{~B}_{4.7}$ and $\mathrm{Pd}_{51.4} \mathrm{Fe}_{18} \mathrm{Co}_{18} \mathrm{Si}_{11.1} \mathrm{~B}_{1.5}$ alloys, before and after heat treatment. The patterns for the as-cast alloys (Figures 1(a) and 2(a)) do not show a peak for any crystalline phase, but that for the heat treated sample has the peaks for crystalline $\mathrm{Pd}_{2} \mathrm{Si}$, $\mathrm{Pd}_{3} \mathrm{Si}, \mathrm{Fe}_{3} \mathrm{Si}$, and $\mathrm{FeB}$ phases as shown in Figures 1(b) and 2(b) [13-16].

The typical potentiodynamic polarization curves of the $\mathrm{Pd}_{48.2} \mathrm{Fe}_{17} \mathrm{Co}_{16.7} \mathrm{Si}_{13.4} \mathrm{~B}_{4.7}$ and $\mathrm{Pd}_{51.4} \mathrm{Fe}_{18} \mathrm{Co}_{18} \mathrm{Si}_{11.1} \mathrm{~B}_{1.5}$ alloys in amorphous and crystalline states are shown in Figure 3. The alloys generally showed passive behavior between the corrosion potential $\left(E_{\text {corr }}\right)$ up to about $0.85 \mathrm{~V}_{\mathrm{SCE}}$. The annealed alloys had a weak anodic peak in current density around $0.4 \mathrm{~V}_{\mathrm{SCE}}$. On the other hand, the passive current density of the amorphous alloys increased gradually without a peak. An oxidation reaction associated with the crystalline phases may have resulted in a slight increase in the passive current density.

$E_{\text {corr }}$ was measured to be $0.07 \sim 0.10 \mathrm{~V}_{\mathrm{SCE}}$ for $\mathrm{Pd}_{48.2} \mathrm{Fe}_{17} \mathrm{Co}_{16.7} \mathrm{Si}_{13.4} \mathrm{~B}_{4.7}$ and $0.09 \sim 0.17 \mathrm{~V}_{\text {SCE }}$ for $\mathrm{Pd}_{51.4} \mathrm{Fe}_{18} \mathrm{Co}_{18} \mathrm{Si}_{11.1} \mathrm{~B}_{1.5}$, as summarized in Figure 4(a). The 


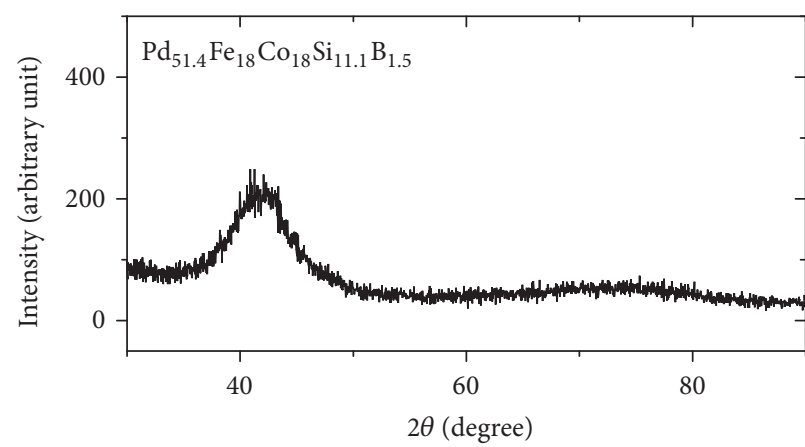

(a) As-cast

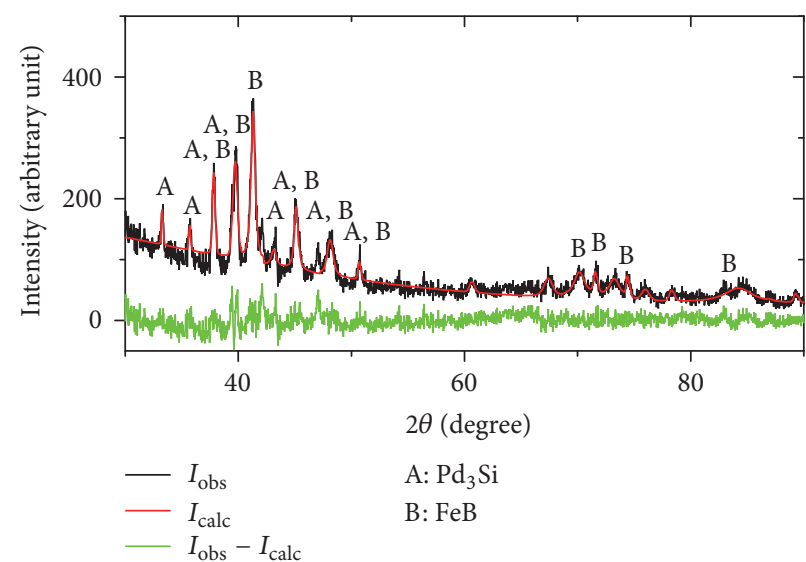

(b) Annealed

FIGURE 2: XRD patterns for (a) amorphous and (b) crystallized $\mathrm{Pd}_{51.4} \mathrm{Fe}_{18} \mathrm{Co}_{18} \mathrm{Si}_{11.1} \mathrm{~B}_{1.5}$ alloys.

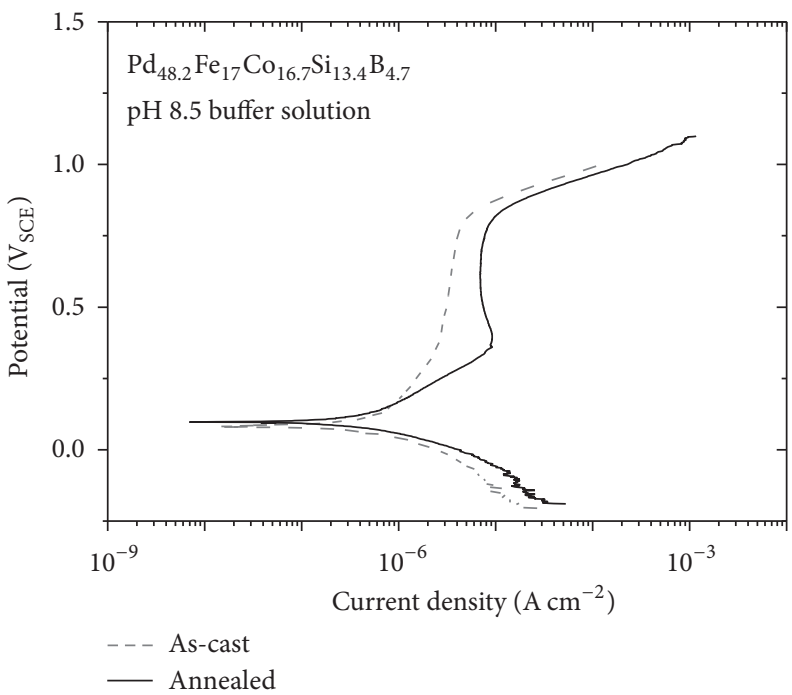

(a)

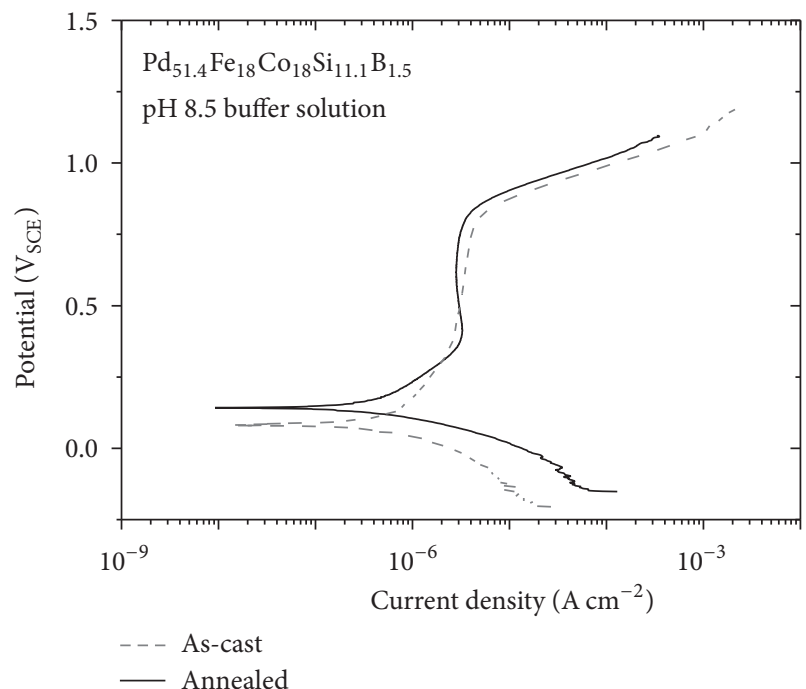

(b)

Figure 3: Potentiodynamic polarization curves of amorphous and crystallized (a) $\mathrm{Pd}_{48.2} \mathrm{Fe}_{17} \mathrm{Co}_{16.7} \mathrm{Si}_{13.4} \mathrm{~B}_{4.7}$ and (b) $\mathrm{Pd}_{51.4} \mathrm{Fe}_{18} \mathrm{Co}_{18} \mathrm{Si}_{11.1} \mathrm{~B}_{1.5}$ alloys measured in $\mathrm{pH} 8.5$ solutions.

passive current densities $\left(i_{\text {pass }}\right)$ were $1.7 \times 10^{-6} \mathrm{~A} / \mathrm{cm}^{2} \sim 3.5$ $\times 10^{-6} \mathrm{~A} / \mathrm{cm}^{2}$ for the amorphous alloys, while being $3.0 \times$ $10^{-6} \mathrm{~A} / \mathrm{cm}^{2} \sim 7.5 \times 10^{-6} \mathrm{~A} / \mathrm{cm}^{2}$ for the crystallized alloys. Both $E_{\text {corr }}$ and $i_{\text {pass }}$ increased by crystallization.

Various kinds of borides and silicides, including $\mathrm{FeB}$, $\mathrm{Fe}_{2} \mathrm{~B}, \mathrm{CoB}, \mathrm{CoSi}$, and $\mathrm{MnSi}$, are reported to be resistant to corrosion or effective in reducing corrosion rate of alloys [1720]. However the passive current density was rather increased for the crystalline alloy with borides and silicides in Figure 4. It implies that the microstructure is much more influential than the precipitation of these phases for the alloys in this study.

We examined the semiconducting properties of passive films by Mott-Schottky analysis. Figure 5 shows the typical Mott-Schottky plots of amorphous and crystalline Pd-based alloys. Linear regions with positive slopes were recognized at potential of $-0.3 \sim-0.1 \mathrm{~V}_{\mathrm{SCE}}$. These plots have very similar features to the Mott-Schottky plots of the passive films formed on stainless steels as known from previous researches $[21,22]$. This result is not astonishing considering the fact that the Mott-Schottky plots for the passive film formed on Alloy 690 in various corrosion environments also resemble the plot for the passive film of iron or stainless steel, although the alloy has only $10 \mathrm{wt} . \%$ of iron [23]. The positive slope of the Mott-Schottky plot indicates that the passive film exhibits n-type semiconductivity with high density of oxygen vacancy, while the negative slope means a p-type passive film with metal vacancy [24]. From the Mott-Schottky plots (Figure 6) for the pure metals, the Pd and Fe are thought to form n-type passive films at potential ranges higher than 


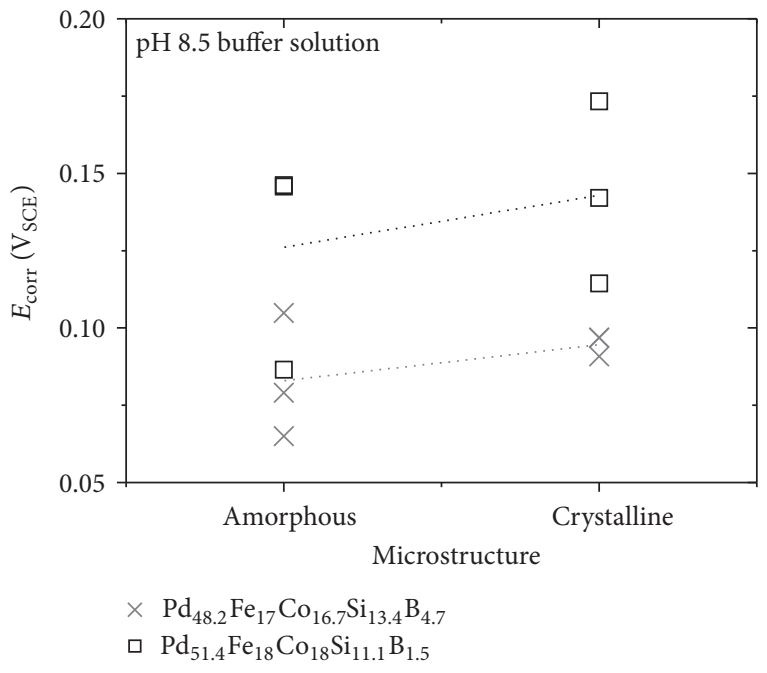

(a)

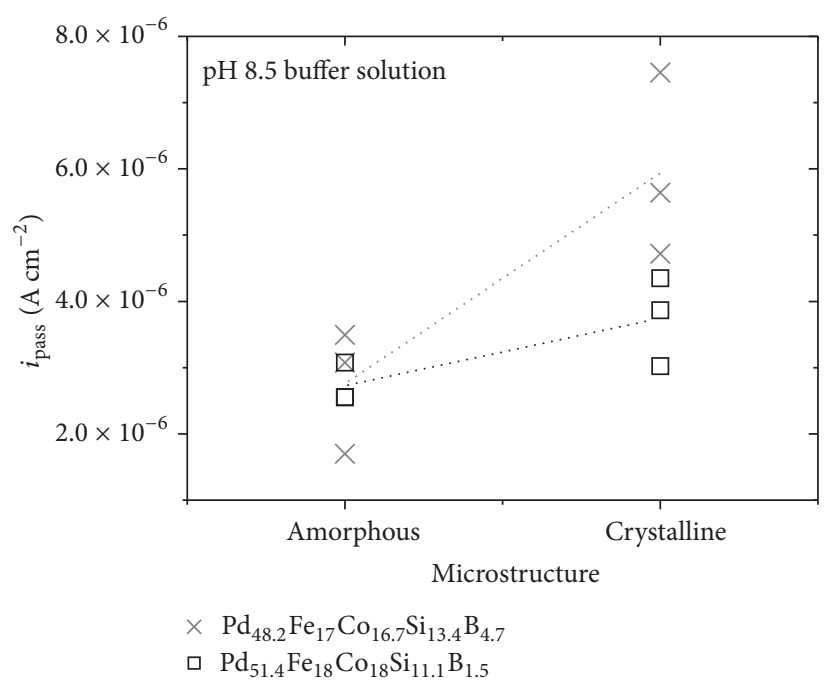

(b)

Figure 4: (a) The corrosion potential and (b) the passive current density for $\mathrm{Pd}_{48.2} \mathrm{Fe}_{17} \mathrm{Co}_{16.7} \mathrm{Si}_{13.4} \mathrm{~B}_{4.7}$ and $\mathrm{Pd}_{51.4} \mathrm{Fe}_{18} \mathrm{Co}_{18} \mathrm{Si}_{11.1} \mathrm{~B}_{1.5}$ alloys in pH 8.5 solutions.

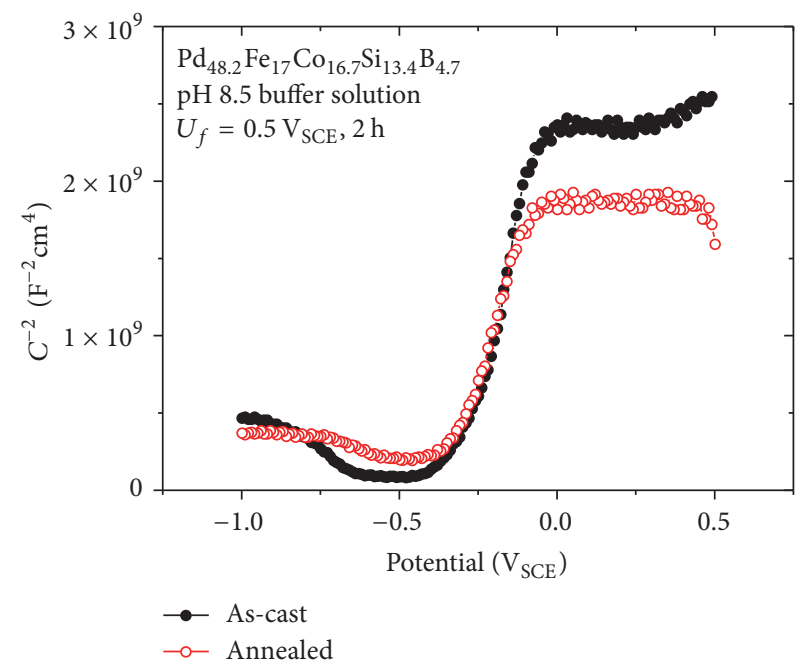

(a)

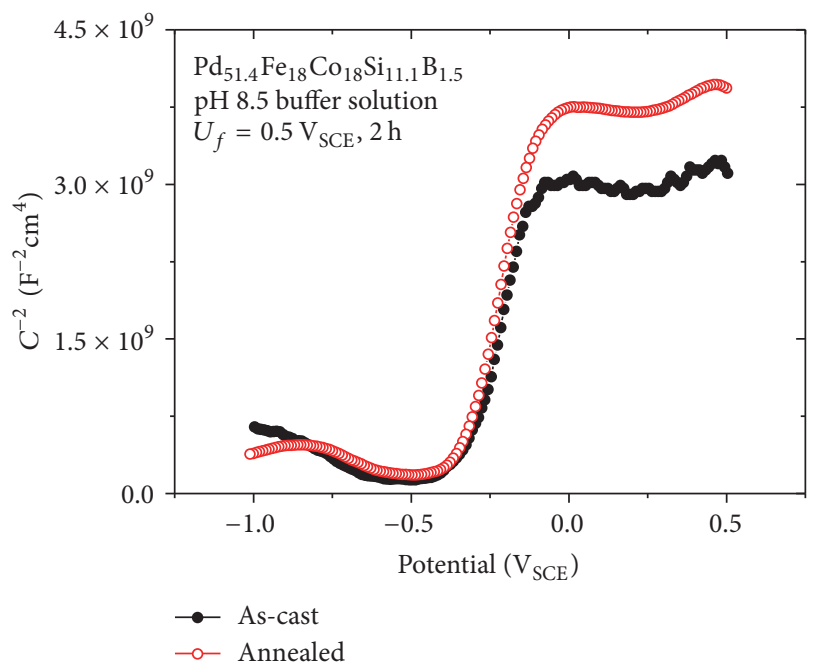

(b)

FIGURE 5: Typical Mott-Schottky plots for the passive films formed on (a) $\mathrm{Pd}_{48.2} \mathrm{Fe}_{17} \mathrm{Co}_{16.7} \mathrm{Si}_{13.4} \mathrm{~B}_{4.7}$ and (b) $\mathrm{Pd}_{51.4} \mathrm{Fe}_{18} \mathrm{Co}_{18} \mathrm{Si}_{11.1} \mathrm{~B}_{1.5}$ at $0.5 \mathrm{~V}_{\mathrm{SCE}}$ for $2 \mathrm{~h}$ in $\mathrm{pH} 8.5$ buffer solution.

$-0.1 \mathrm{~V}_{\mathrm{SCE}}$ and $-0.3 \mathrm{~V}_{\mathrm{SCE}}$, respectively. However the passive film of Co shows p-type behavior below $-0.5 \mathrm{~V}_{\text {SCE }}$ and ntype behavior at high potentials (Figure 6(c)). Therefore, the Pd-based alloys studied in this work are regarded to have ntype semiconductivity predominated by Fe oxide, from the conducting type and the flat band potential.

The donor density, which means the density of oxygen vacancy practically, for the passive films was determined from the Mott-Schottky plots, assuming the dielectric constant as 15.6 [25]. The dielectric constants of the passive film of Pdbased alloys are not known, actually. We note that a value of 15.6, generally accepted for the passive film of stainless steels, was used to analyze the dependence of the defect density on the microstructure. This is based on the fact that the capacitance behavior of the alloys in this study is very close to that of stainless steels. The donor density, $N_{d}$, which represents the concentration of oxygen vacancy, is shown in Figure 7. The value of $N_{d}$ was calculated to be $2.0 \times 10^{20} \mathrm{~cm}^{-3} \sim$ $5.6 \times 10^{20} \mathrm{~cm}^{-3}$. Crystallization by heat treatment seems to increase the defect density of the passive film, and the level of influence was not different from alloy to alloy. These results suggest a possibility that the defect density in the passive film 


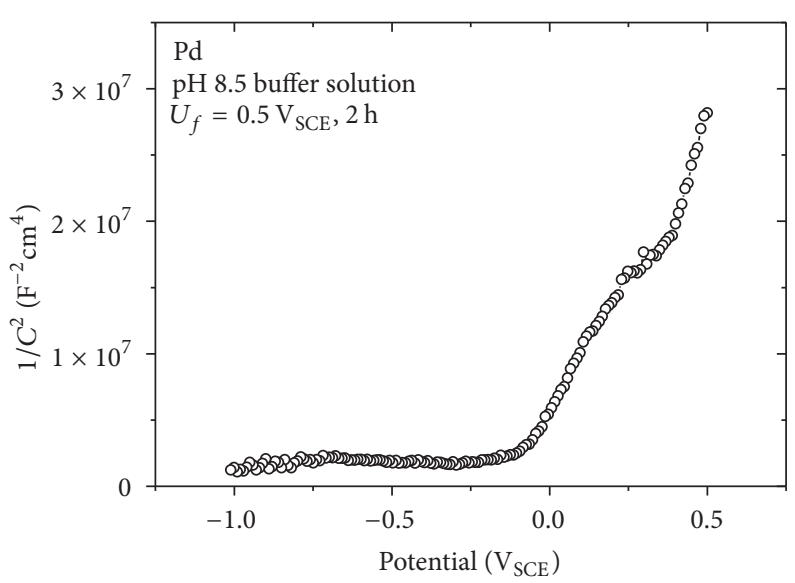

(a)

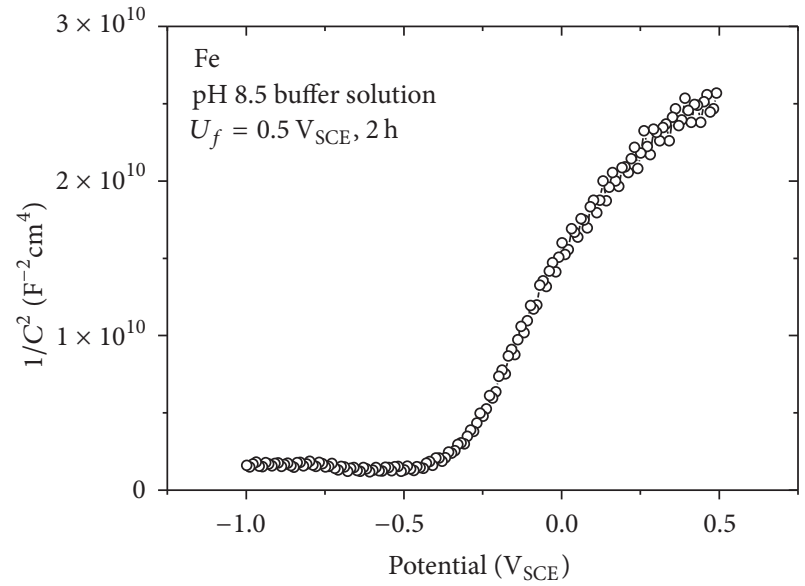

(b)

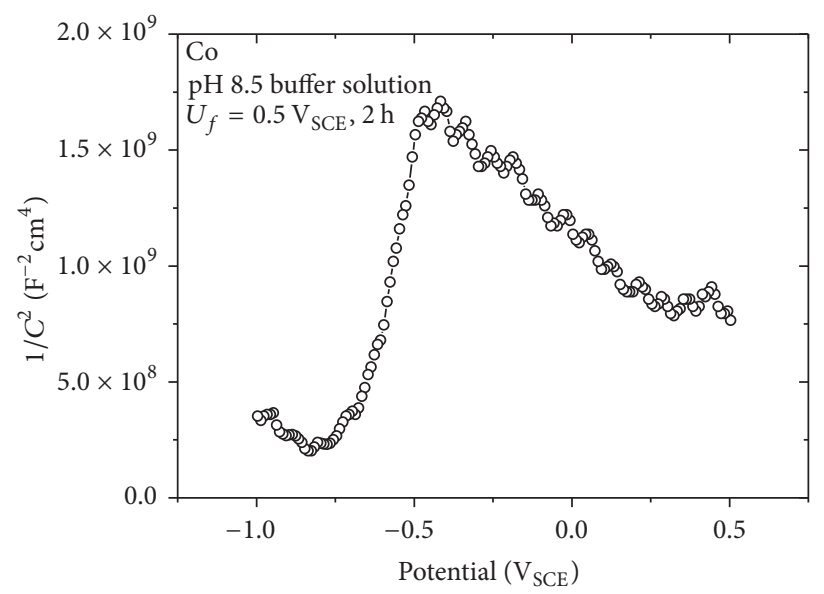

(c)

FIGURE 6: Mott-Schottky plots for the passive films formed on (a) Pd, (b) Fe, and (c) Co at $0.5 \mathrm{~V}_{\mathrm{SCE}}$ for $2 \mathrm{~h}$ in pH 8.5 buffer solution.

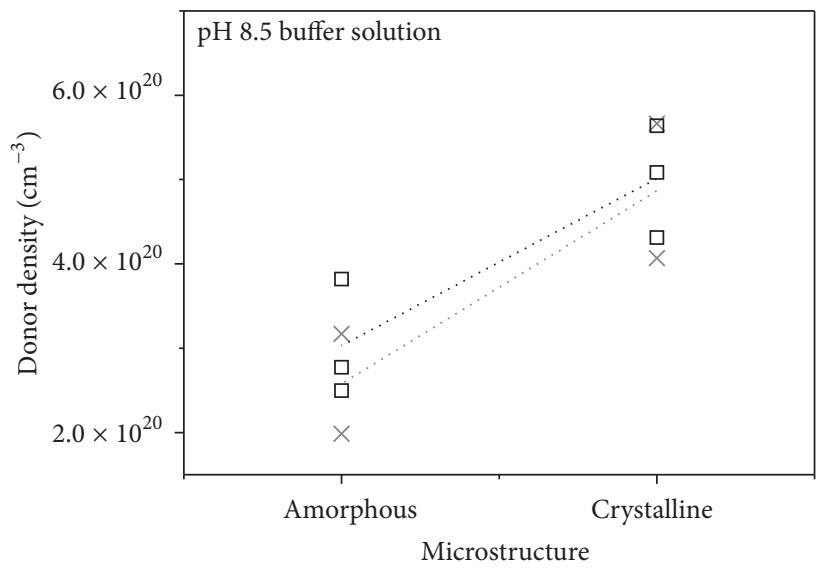

$\times \mathrm{Pd}_{48.2} \mathrm{Fe}_{17} \mathrm{Co}_{16.7} \mathrm{Si}_{13.4} \mathrm{~B}_{4.7}$

$\mathrm{Pd}_{51.4} \mathrm{Fe}_{18} \mathrm{Co}_{18} \mathrm{Si}_{11.1} \mathrm{~B}_{1.5}$

FIgURE 7: Donor density of the passive films on $\mathrm{Pd}_{48.2} \mathrm{Fe}_{17} \mathrm{Co}_{16.7} \mathrm{Si}_{13.4} \mathrm{~B}_{4.7}$ and $\mathrm{Pd}_{51.4} \mathrm{Fe}_{18} \mathrm{Co}_{18} \mathrm{Si}_{11.1} \mathrm{~B}_{1.5}$ alloys. 
may be related to the passive current density or the corrosion resistance. However, changes in defect density and corrosion resistance do not have a quantitative linear relationship.

\section{Conclusions}

Corrosion behavior and the electronic properties of the passive films of $\mathrm{Pd}_{48.2} \mathrm{Fe}_{17} \mathrm{Co}_{16.7} \mathrm{Si}_{13.4} \mathrm{~B}_{4.7}$ and $\mathrm{Pd}_{51.4} \mathrm{Fe}_{18} \mathrm{Co}_{18} \mathrm{Si}_{11.1} \mathrm{~B}_{1.5}$ alloys in amorphous and crystalline states were examined in pH 8.5 buffer solution.

The alloys showed wide passive regions with the passive current density of about $1.7 \times 10^{-6} \mathrm{~A} / \mathrm{cm}^{2} \sim 7.5 \times 10^{-6} \mathrm{~A} / \mathrm{cm}^{2}$. The crystalline alloys were found to have a higher current density with the amorphous alloys with the same composition.

Mott-Schottky analysis suggests that the passive films formed on the Pd-based alloys in this study have n-type semiconductivity. The donor density, which represents the concentration of oxygen vacancy in the passive film, was measured to be $1.7 \times 10^{-6} \mathrm{~A} / \mathrm{cm}^{2} \sim 3.5 \times 10^{-6} \mathrm{~A} / \mathrm{cm}^{2}$ and increased by heat treatment of the alloys. The lower corrosion resistance of crystalline alloys may be associated with higher defect density, although any direct relationship was not established.

\section{Conflicts of Interest}

The authors declare that they have no conflicts of interest.

\section{Acknowledgments}

This work was supported by research fund from Chosun University, 2016.

\section{References}

[1] A. Inoue, Japan Nanonet Bulletin, 2 (2004) $14^{\text {th }}$ issue, Mar. 18, 1-3.

[2] A. Inoue, B. Shen, and A. Takeuchi, "Fabrication, properties and applications of bulk glassy alloys in late transition metal-based systems," Materials Science and Engineering A, vol. 441, no. 1-2, pp. 18-25, 2006.

[3] A. Inoue, B. Shen, H. Koshiba, H. Kato, and A. R. Yavari, "Cobalt-based bulk glassy alloy with ultrahigh strength and soft magnetic properties," Nature Materials, vol. 2, no. 10, pp. 661663, 2003.

[4] C. Beatrice, N. Banu, E. Ferrara, and F. Fiorillo, "Highfrequency properties of thin amorphous ribbons," Journal of Magnetism and Magnetic Materials, vol. 320, no. 20, pp. e810e813, 2008.

[5] F. F. Marzo, A. R. Pierna, J. Barranco et al., "Determination of trace metal release during corrosion characterization of FeCobased amorphous metallic materials by stripping voltammetry. New materials for GMI biosensors," Journal of Non-Crystalline Solids, vol. 354, no. 47-51, pp. 5169-5171, 2008.

[6] Z. Ma, L. Zhang, R. Chen, W. Xing, and N. Xu, "Preparation of Pd-B/TiO2 amorphous alloy catalysts and their performance on liquid-phase hydrogenation of p-nitrophenol," Chemical Engineering Journal, vol. 138, no. 1-3, pp. 517-522, 2008.
[7] Y. Lou, Y.-T. Shao, P. Li, Z.-L. Li, and Z.-J. Niu, "Electrocatalytic reduction of NO3- in a neutral solution on an electrodeposited film of amorphous Pd33Ni60P7 alloy," Journal of Electroanalytical Chemistry, vol. 624, no. 1-2, pp. 33-38, 2008.

[8] X. WU and C. XIE, "Influence of crystallization on corrosion resistance of Al86Ni6La6Cu2 amorphous alloy," Journal of Rare Earths, vol. 26, no. 5, pp. 745-748, 2008.

[9] H. A. Shivaee, A. N. Golikand, H. R. M. Hosseini, and M. Asgari, "Influence of annealing on the electrochemical behavior of finemet amorphous and nanocrystalline alloy," Journal of Materials Science, vol. 45, no. 2, pp. 546-551, 2010.

[10] S.-S. Shin, C.-M. Lee, J.-W. Yang, and J.-C. Lee, Journal of the Korean Institute of Metals and Materials, vol. 46, pp. 53-57, 2008.

[11] Y.-F. Wu, W.-C. Chiang, J. Chu, T.-G. Nieh, Y. Kawamura, and J.-K. Wu, "Corrosion resistance of amorphous and crystalline Pd40Ni40P20 alloys in aqueous solutions," Materials Letters, vol. 60, no. 19, pp. 2416-2418, 2006.

[12] H. Jang and H. Kwon, "Photoelectrochemical analysis of passive films formed on $\mathrm{Ni}$ and its alloys and its application to their corrosion behaviors," Journal of Solid State Electrochemistry, vol. 19, no. 12, pp. 3427-3438, 2015.

[13] A. Inoue, T. Aoki, and H. Kimura, "Effect of B addition on extension of supercooled liquid region before crystallization in Pd-Cu-Si amorphous alloys," Materials Transactions, JIM, vol. 38, no. 2, pp. 175-178, 1997.

[14] T. D. Shen, Y. He, and R. B. Schwarz, "Bulk amorphous PdNi-Fe-P alloys: preparation and characterization," Journal of Materials Research, vol. 14, no. 5, pp. 2107-2115, 1999.

[15] I. Mat'ko, E. Illekova, P. Svec, P. Duhaj, and K. Czomorova, Materials Science \& Engineering: A, pp. 226-228, 1997.

[16] E. Jakubczyk, Z. Mandecki, and J. Filipecki, "Crystallization process for the metallic glass Fe18Co 60Si9B13," Journal of NonCrystalline Solids, vol. 192-193, pp. 509-512, 1995.

[17] D. N. Tsipas, H. Noguera, and J. Rus, "Corrosion behaviour of boronized low carbon steel," Materials Chemistry and Physics, vol. 18, no. 3, pp. 295-303, 1987.

[18] I. Campos, M. Palomar, A. Amador, R. Ganem, and J. Martinez, "Evaluation of the corrosion resistance of iron boride coatings obtained by paste boriding process," Surface and Coatings Technology, vol. 201, no. 6, pp. 2438-2442, 2006.

[19] L.-F. Jiao, H.-T. Yuan, Y.-J. Wang, and Y.-M. Wang, "Electrochemical properties of magnesium-based hydrogen storage alloys improved by transition metal boride and silicide additives," International Journal of Hydrogen Energy, vol. 34, no. 3, pp. 1476-1482, 2009.

[20] A. B. Shein and E. N. Zubova, "Electrochemical behavior of manganese silicides in sulfuric acid solution," Protection of Metals, vol. 41, no. 3, pp. 234-242, 2005.

[21] H. Jang and H. Kwon, "In situ study on the effects of $\mathrm{Ni}$ and Mo on the passive film formed on Fe-20Cr alloys by photoelectrochemical and Mott-Schottky techniques," Journal of Electroanalytical Chemistry, vol. 590, no. 2, pp. 120-125, 2006.

[22] M. Ferreira, N. Hakiki, G. Goodlet, S. Faty, A. Simões, and M. Da Cunha Belo, "Influence of the temperature of film formation on the electronic structure of oxide films formed on 304 stainless steel," Electrochimica Acta, vol. 46, no. 24-25, pp. 3767-3776, 2001.

[23] H. Jang and H. Kwon, "Corrosion Science and Technology," vol. 5, pp. 141-148, 2006.

[24] D. D. MacDonald, "The history of the Point Defect Model for the passive state: A brief review of film growth aspects," Electrochimica Acta, vol. 56, no. 4, pp. 1761-1772, 2011. 
[25] H. Jang, C. Park, and H. Kwon, "Photoelectrochemical analysis of the effects of $\mathrm{pH}$ and sulfate ions on the structure and the composition of the passive film formed on Fe-20Cr-15Ni alloy," Metals and Materials International, vol. 15, no. 1, pp. 57-62, 2009. 

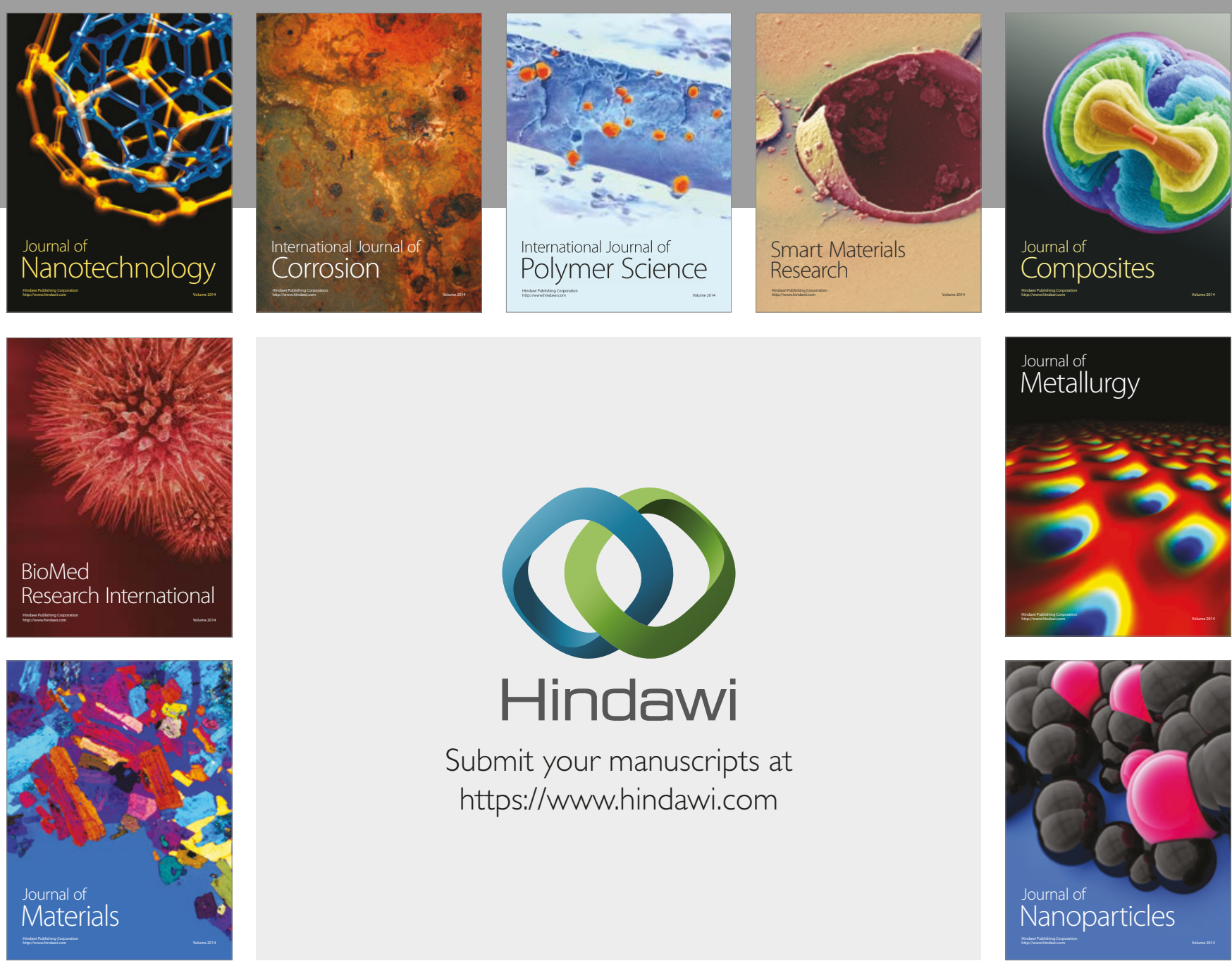

\section{Hindawi}

Submit your manuscripts at

https://www.hindawi.com
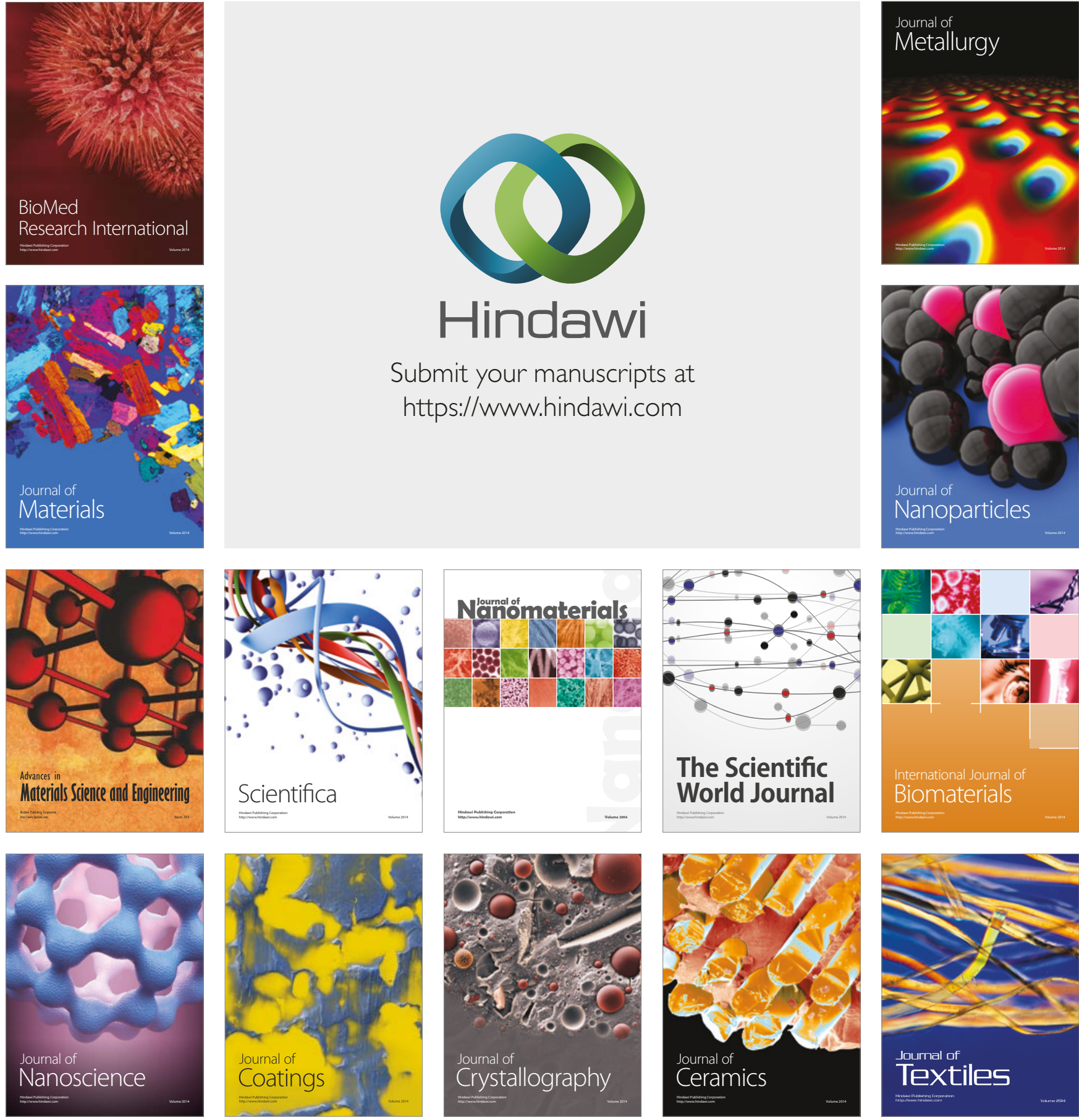

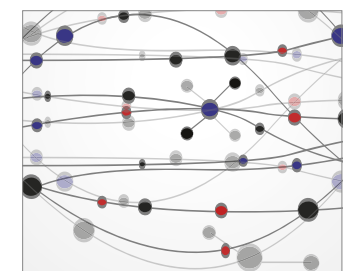

The Scientific World Journal
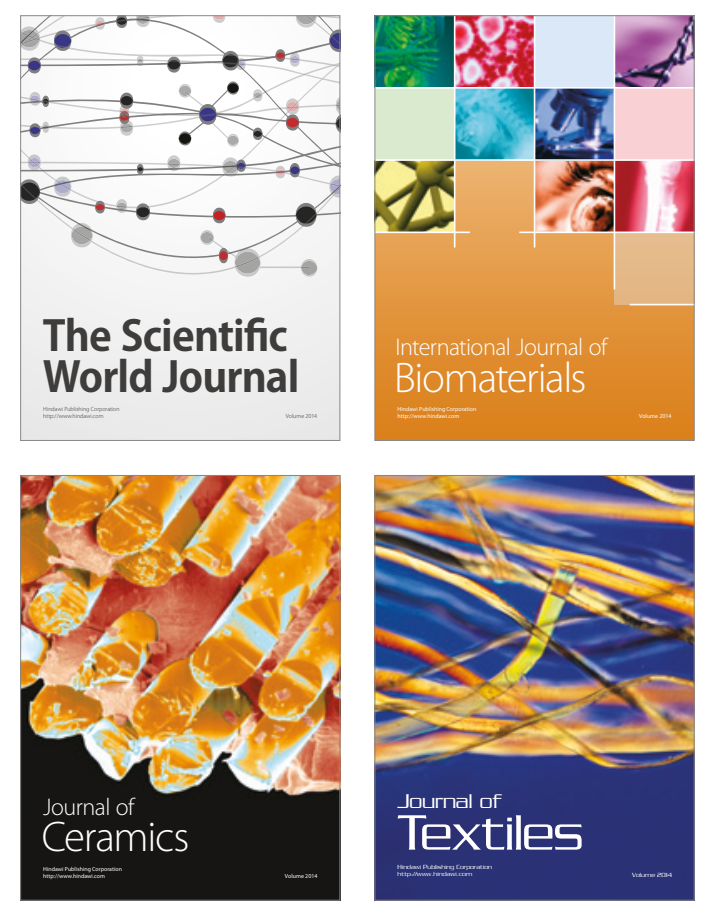